Potomac River to the south, the Ohio River in the west, and many other places ; $(5)$ The Heteropygii have three genera (as understood by Putnam, the only naturalist who has thoroughly studied them) confined to the western and southern states; (6) The genus Paralobrax is an entirely marine one, very closely (6) The genus Paralobrax is an entirely marine one, very closely extensively on the western coast of America, as well as elsewhere in the Pacific Ocean; (7) Huro nigricans (the only species) is a in the Pacitic Ocean ; to Florida in the south-east, and Mexico toward the south-west ; (8) Pileoma is a later name for Percina; (9) Bryttus and (I) Pomotis are not Percida according to most American authors, nor according to Dr. Giinther's recently promulgated views (the vertebræ being only $A$ Io $+C_{14}$ ), and belong to a quite peculiar family ; (II) Hypodelus is a misnomer for Hopladelus; (12) Thaleichthy's is as much a marine genus as Osmerus (Smelts); there is no such restriction at all as indicated by the remarks on the distribution of (I3) Moxostoma, (14) Pimephales, (15) Hyborhynchus, and (I6) Rhinichthys on the one hand, and (17) Ericymba, (18) Exoglossum, (19) Leucosomus, (= Semotilus), and (20) Carpiodes on the other; and the categories might indeed, as to most causes, be almost reversed; (2r) Mylaphorodon is a misnomer for Mylopharodon. The number of genera enumerated as peculiar might, too, be very safely more than doubled, and by reference to Giinther's work and subsequent corrections, Centrarcluts, Ptyonotus (= Triglopsis), and Hysterocarpus could have been added. All these errors might have been prevented if Mr. Wallace had been familiar with ichthyology and its literature. The paragraph cited also quite conceals the remarkable distribution into secondary faunas of the American genera, and is calculated to entirely mislead respecting the contrasts between North America and the Old World. His use of the term "Eartern States" (instead of "Eastern Province," as Baird calls the division meant) is confusing, inasmuch as it is a geographical designation for a particular group of states.

Smithsonian Institulion, Washington,

$$
\text { September } 2 \mathbf{I}
$$

ThHo. Gill

\section{The Self-Fertilisation of Plants}

UNDER this title there is an article in Nature, vol. xiv. p. 475 mentioning some observations on flowers, and concluding thus :- "In view of these examples .... it can hardly be that colour, fragrance and honeyed secretions in flowers have been developed solely to secure cross-fertilisation." In reply to this article it may be worth showing that of the examples relied upon the first and last are most probably incorrectly observed and erroneously interpreted, whilst the others are of no consequence at all, so far as the good effects of cross-fertilisation are concerned.

First, the flowers of Browallia elata have been most accurately described by $\mathrm{F}$. Delpino ("Ulteriori osservazioni sulla dicogamia nel regno vegetale," Parte I. p. I4O-143), and this excellent observer has fully convinced himself that it is cross-fertilised whenever it is visited by Lepidoptera or Bombylius.

Claytonia virginica and Ranunculus bulbosus simply confirm the well-known fact that many flowers have recourse to self-fertilisation when not visited by insects (see H. Müller's "Befruch tung," p. 443-448, NATURE, vol. viii. p. 433, vol. ix. pp. 44, 64, vol, $x$, p. I22).

As to the last example, Ranunculus abortivus, it is inadmissible to conclude from the fact that one has not observed visitors on a plant, that this plant is wholly neglected by insects.

Wilh regard to the article as a whole, it seems to me somewhat rash to call in question a comprehensive and well-founded theory on the basis of a few superficial observations.

Lippstad, October 20 HermanN MÜlleR

\section{The Proposed Zoological Stations at $\mathrm{Kiel}$ and Heligoland}

IN NATURE, vol. xiv. p. 535, there appears amongst the occasional Notes, a short report of a proposal of the Association of German Naturalists to found two new Zoological Stations at Kiel and Heligoland. The establishment of such stations could not fail to be of immense service to biology, but it is much to be regretted that the Association is inclined to put aside the claims of the present Zoological Station at Naples in favour of these two new institutions. To act in this way would be both unwise and ungenerous : unwise, because a station on the shores of the Mediterranean can obtain a great variety of forms which are not to be found in the North Sea and the Baltic; and ungenerous because the Naples Station has been the means of proving both the value and feasibility of such institutions, and without it the present proposals would never have originated. It is indeed surprising to see a body of German naturalists refusing their support to an institution like that at Naples, which has already rendered such signal services to biology, in which so many of themselves have made important discoveries, and which is, more. over, founded almost on the site of the classical investigations of Kölliker, Gegenbaur, and Hæckel.

It is to be hoped that the Commission appointed by the Asso. ciation to draw up a memorandum will see their way to urging the claims of the existing Zoological Station at Naples without thereby interfering with the prospects of the similar institutions which it is proposed to found.

Trinity College, Cambridge

F. M. BALFOUR

\section{The Flame of Chloride of Sodium in a Common Coal Fire}

Mr. Hardman, in Nature, vol. xiv. p. 506, gives an account of a number of experiments which he considers to bear out the old theory that the blue flame produced by throwing common salt on a coal fire is due to carbonic oxide. His letter induces me to give an account of a series of experiments which I made last winter, in company with Mr. R. A. Lundie, and which led me to an exactly opposite conclusion. Our experiments were all made with the help of a spectroscope, no dependence being put on observations made with the naked eye :-

I. We examined, with the spectroscope (which was a small direct-vision one), a very distinct blue flame of $\mathrm{CO}$, burning in a coal fire; this, as far as we could see, gave no bright lines. A little common salt was then put on the fire, when at once a very marked spectrum appeared, the most characteristic part of which was a pair of bright lines in the blue, and another pair in the violet beyond the spectrum of the glowing coals, against which the flame was generally seen. This flame was very persistent, and frequently long after the flame had ceased to be distinguishable, the spectrum was still quite marked.

2. We did not succeed in getting the spectrum with other salts of soda, such as carbonate, phosphate, and borate; nor yet with microcosmic salt, while on the other hand, with other chlorides and chlorates, such as $\mathrm{KCl}, \mathrm{KClO}_{3}$, and $\mathrm{NHI}_{4} \mathrm{Cl}$ almost exactly the same spectrum was obtained, and with bromide of potassium a very similar, if not an identical, spectrum was also obtained.

3. We were able, but with more difficulty, to get the charac. teristic spectrum, when a blow-pipe flame was made to play down on chloride of soda, or ammonia, lying on an iron plate; and in this case it was observed that the blue flame seemed to be produced only when the flame which had passed over the salt came to a colder part of the plate where there was more salt.

Want of time has preven'ed me from continuing my experiments, and $I$ do not venture to suggest any theory to account for the phenomenon. It is possible that part of the blue blaze is due to carbonic oxide, but I am convinced that this is not a complete explanation. Neither do I think that Mr. Muiller's explanation (NATURE, vol. xiii. p. 448) is sufficient, though a number of our earliest experiments, in which a brass plate took the place of the iron plate (in experiment 3 ), certainly favour this explanation to a certain extent. The flame thus produced gave the characteristic spectrum very brightly, but at the same time new lines (copper) appeared in the green. I would add that I have as yet been unable to get satisfactory measurements of the positions of the lines, the spectroscope I used for most of my observations having no micrometer nor scale.

Keig, Aberdeenshire, October 13

C. Michie Smith

\section{OUR ASTRONOMICAL COLUMN}

The INTRA-MERCURIAL Planet QUESTION.-M. Leverrier has made a further communication to the Paris Academy on this subject. With the view to testing the sufficiency of the method employed, to afford a guide for prediction of future transits of such a body over the sun's disk, admitting that the observations in which appre ciable motion is recorded really refer to an intra-Mercurial planet, he applies it in the case of Mercury. Tran- 